\title{
The Corneomandibular Reflex and the race of the reflexes: Clinical and Historical Aspects
}

\section{O reflexo córneo-mandibular e a corrida dos reflexos: aspectos clínicos e históricos}

\author{
Timóteo A. L. Almeida ${ }^{1}$ Ricardo M. Camelo ${ }^{2}$ Fernanda G. B. Araújo ${ }^{3}$ \\ ${ }^{1}$ Department of Neurosurgery, Hospital São Vivente de Paulo, \\ Rio Grande do Sul, Brazil \\ 2 Department of Neurosurgery, Universidade Federal de Alagoas, \\ Maceió, Brazil \\ ${ }^{3}$ Neonatal Intensive Care Unit, Hospital São Vicente de Paulo, \\ Rio Grande do Sul, Brazil

\begin{abstract}
Address for correspondence Timóteo A. L. Almeida, MD, Department of Neurosurgery, Hospital São Vivente de Paulo, Rio Grande do Sul, Brazil (e-mail: timoteo.md@gmail.com).
\end{abstract} \\ Arq Bras Neurocir 2016;35:304-306.
}
Abstract
The corneomandibular reflex was first described in 1902 by German doctor Von Sölder, Keywords who reported the presence of the reflex in patients and in the general population. For
- corneomandibular reflex
- historical note
- semiology

\section{Resumo \\ Palavras-chave \\ - reflexo córneo- mandibular \\ - nota histórica \\ - semiologia} him, the corneomandibular reflex represented an exaggeration of the normal response. This was one of the more than 250 reflexes described in the beginning of the $20^{\text {th }}$ century, during the so called "race of the reflexes".
O reflexo córneo-mandibular foi descrito pela primeira vez em 1902 pelo alemão Von Sölder, que relatou a presença de reflexos em pacientes e indivíduos normais. Segundo ele, o reflexo córneo-mandibular representa um exagero da resposta convencional. Este é um dos mais de 250 reflexos descritos no início do século XX, durante a chamada "corrida dos reflexos".

\section{Introduction}

After the description of the patellar reflex in 1875 by Wilhelm Erb, then using the forgotten instrument of Pierre Adolphe Piorry, the former percussion instrument began to be used in the study of deep reflexes, and is now known as the reflex hammer. Thus, Wilhelm Erb described using the hammer for the first time in the study of the patellar reflex, in that "with every tap the peculiar tickling or itching sensation may be perceived in the tendon."

During the nineteenth century, there was a real "race of the reflexes." Hundreds of papers were published describing new reflections from using the hammer, so that, in 1945, there were $\sim 250$ reflections described. $^{2}$ Most of these reflections were present only in patients with neuronal abnormality as they are typically absent in normal people. ${ }^{3}$ This feature further stimulated the search for information that could assist in clinical diagnosis.

The corneomandibular reflex was first described in 1902 by the German doctor Von Sölder, who reported the presence of the reflex in patients and normal people. For him, the corneomandibular reflex represented an exaggeration of the normal response. ${ }^{4}$ Although described by Von Sölder in 1902 and again in 1918 by Trömmer, it was after the work of Wartenberg in 1948, through a detailed description of what he called "the jaw wincking received

September 14, 2015

accepted

December 1, 2015

published online

February 24, 2016
DOI http://dx.doi.org/

10.1055/s-0036-1579659. ISSN $0103-5355$.
Copyright $\odot 2016$ by Thieme-Revinter

Publicações Ltda, Rio de Janeiro, Brazil
License terms

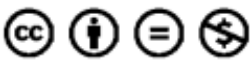


phenomenon" that the corneomandibular reflex became best known. ${ }^{5}$

According to Wartenberg, the corneomandibular reflex was a related motion of the orbicularis of the eye and the external pterygoid muscles, because a supranuclear lesion of the trigeminal nerve, which occurred when the cornea of the hemiplegic side was stimulated. ${ }^{6}$ Subsequently, Paulson and Gottlieb described the corneomandibular reflex in six patients with senile dementia. ${ }^{7}$ In his work, DeJong describes this reflex as a associated movement rather than a reflex itself. $^{8}$

In 1962, Ansink reported the presence of the corneomandibular reflex in $2 \%$ of patients younger than 6 months, $6 \%$ of patients between 20 and 45 years, and $34 \%$ of patients between 65 and 92 years of age without neurological disease, distinguishing between the normal reflex and abnormal reflex. According Ansink, the presence of the reflex was consequent to brain stem lesion or was one of the early and most sensitive sign of tentorial herniation. ${ }^{9}$

The cornea is innervated by myelinated fibers (A-delta) and non-myelinated (C). After entering the cornea, the myelinated fibers lose their myelin fibers and both ends as free nerve endings. The afferent pathway of the corneomandibular reflex is similar to that of the corneal-palpebral reflex and involves A-delta fibers crossing long ciliary nerves and the ophthalmic branch of the trigeminal nerve. Communication with the efferent pathway occurs via trigeminal interneurons in the bulbar lateral reticular formation, communicating next with the motor branch of the trigeminal nerve that innervates the inferior lateral pterygoid muscle (-Fig. 1). In an eletroneuromyographic study, the long latency after stimulation of the cornea suggests the presence of multiple synaptic connections in the mesencephalon. ${ }^{10}$

Gordon and Bender describe the technique for performing the corneomandibular reflex in their article published in

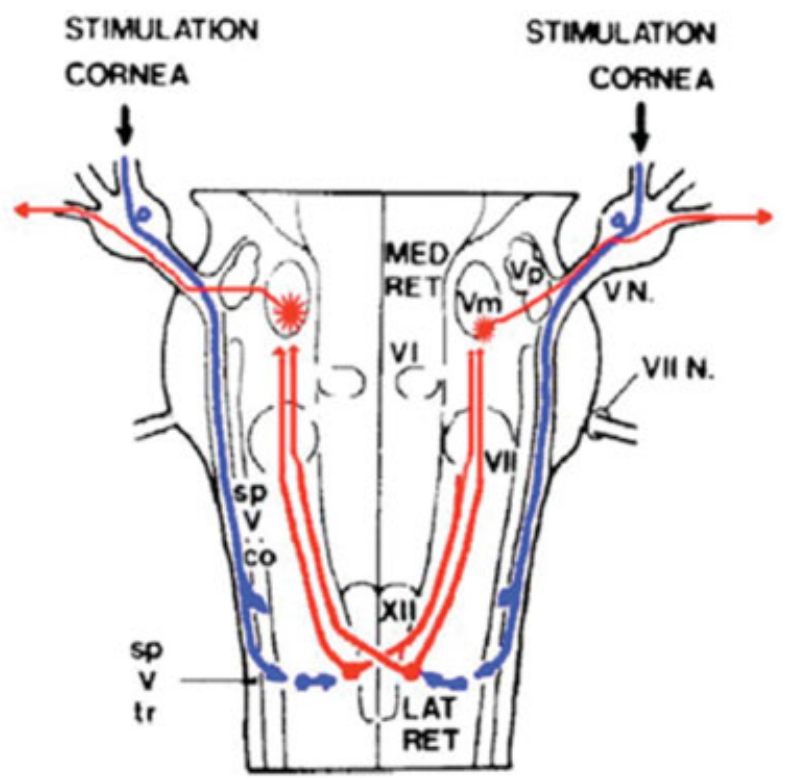

Fig. 1 Neuronal pathways of the corneomandibular reflex. Modified from Aramideh and Visse, 2002.

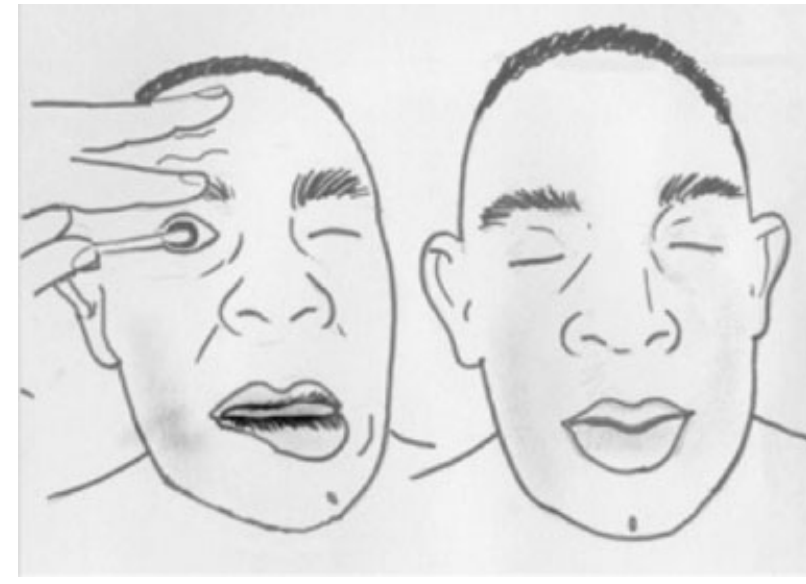

Fig. 2 Illustration of the corneomandibular reflex technique. After the stimulation of the cornea we see a contralateral deviation of the mandible.

1971: "a strong stimulation of each cornea with a sterile cotton tip rod results in the simultaneous closing of both eyes and unilateral deviation of the mandible to the opposite side to the stimulated cornea" (-Fig.2). Compared with the reflex found in some normal people, the authors describe the corneomandibular reflex as easier to monitor and of greater duration in patients with neurological impairment. ${ }^{4}$ They further described seven patients who had prominent corneomandibular reflex and reported three findings common to these patients: the bilateral presence of the reflex, lowering the level of consciousness, and the presence of severe neurological abnormalities, usually of the motor type.

Moreover, the incidence of the corneomandibular reflex is increased in patients with Parkinson's disease. ${ }^{11}$ Gossman and Jacobs found a $21 / 2$ higher incidence in patients with Parkinson's, compared with the incidence in normal people. In a study evaluating the presence of primitive reflexes with the severity of Parkinson's disease, the presence of the corneomandibular reflex and the palmomental reflex were associated with the severity of the disease $(p<0.01)$ and the severity of dementia in patients with Parkinson's disease $(p<0.01) .{ }^{12}$ Unlike the glabelar reflex, characteristically found in patients with Parkinson's, the corneomandibular reflex has no relation with the dopamine level, although more specific to the detection of severe cases of Parkinson's. ${ }^{13}$

Other neurological diseases are associated with the presence of the corneomandibular reflex. In a study of 42 patients with amyotrophic lateral sclerosis, 30 patients had the corneomandibular reflex with other primitive reflexes absent, with its presence being a sensitive indicator of lesion of upper motor neuron. ${ }^{14}$ Guberman evaluated 50 patients with corneomandibular reflex, correlating its presence with acute neurological disease with lower level of consciousness and increased intracranial pressure. The reflex was found in patients with lesions on brainstain or diencephalon, intracranial hypertension, amyotrophic lateral sclerosis with the implication of the corticobulbar pathways, or multiple sclerosis. ${ }^{15}$ 
Although its presence does not specifically point towards any specific neurological disorder, the study of the corneomandibular reflex in patients with neurological involvement can help determine the degree of neurological impairment and prognosis. The presence of the sign is useful in determining the level of injury, typically in the upper trunk injury, as evidence of uncal or transtentorial herniation in acute supratentorial processes, such as a sensitive signal of supraspinal involvement in amyotrophic lateral sclerosis and the assessment of Parkinson's disease severity. Nontheless, as Isakov et al pointed out, the corneomandibular reflex presents diagnostic value in patients with neurological injury only associated with other primitive reflexes (snout reflex or palmomental reflex). ${ }^{16}$

\section{References}

1 Erb WH. Ueber Sehnenreflexe bei Gesunden und Rückenmarkskranken. Arch Psychiatr Nervenkr 1875;5:792-802

2 Wartenberg R. The examination of reflexes, a simplification, foreword by Foster Kennedy. Chicago1945;7:4

3 Hoffmann P. Über die natur der sehnenreflexe (eigenreflexe) und ihr verhältnis zur sensomotilität. Dtsch Z Nervenheilkd 1924; 82:269-280

4 Gordon RM, Bender MB. The corneomandibular reflex. J Neurol Neurosurg Psychiatry 1971;34(3):236-242
5 Schott JM, Rossor MN. The grasp and other primitive reflexes. J Neurol Neurosurg Psychiatry 2003;74(5):558-560

6 Wartenberg R. Winking-jaw phenomenon. Arch Neurol Psychiatry 1948;59(6):734-753

7 Paulson G, Gottlieb G. Development reflexes: the reappearance of foetal and neonatal reflexes in aged patients. Brain 1968; 91:37-52

8 DeJong RN. The neurologic examination. Harper \& Brothers, New York, 1950:21

9 Ansink J. Physiologic and clinical investigations into 4 brain stem reflexes. Neurology 1962;12:320-328

10 Aramideh M, Ongerboer de Visser BW. Brainstem reflexes: electrodiagnostic techniques, physiology, normative data, and clinical applications. Muscle Nerve 2002;26(1):14-30

11 Okuda B, Kawabata K, Tachibana H, Kamogawa K, Okamoto K. Primitive reflexes distinguish vascular parkinsonism from Parkinson's disease. Clin Neurol Neurosurg 2008;110(6):562-565

12 Huber SJ, Paulson GW. Relationship between primitive reflexes and severity in Parkinson's disease. J Neurol Neurosurg Psychiatry 1986;49(11):1298-1300

13 Huber SJ, Paulson GW. Influence of dopamine and disease severity on primitive reflexes in Parkinson's disease. Eur Neurol 1989; 29(3):141-144

14 Okuda B, Kodama N, Kawabata K, Tachibana H, Sugita M. Corneomandibular reflex in ALS. Neurology 1999;52(8):1699-1701

15 Guberman A. Clinical significance of the corneomandibular reflex. Arch Neurol 1982;39(9):578-580

16 Isakov E, Sazbon L, Costeff H, Luz Y, Najenson T. The diagnostic value of three common primitive reflexes. Eur Neurol 1984;23(1): $17-21$ 